\title{
Retraction Note: Molecular mechanisms in progression of HPV-associated cervical carcinogenesis
}

Sadhana M. Gupta* and Jayanti Mania-Pramanik

Retraction to Journal of Biomedical Science (2019) 26:28

https://doi.org/10.1186/s12929-019-0520-2

The Editor-in-Chief has retracted this article [1] due to significant overlap with previously published articles $[2-5]$. Both authors agree with this retraction.

Received: 28 June 2019 Accepted: 28 June 2019

Published online: 04 July 2019

\section{References}

1. Gupta SM, Mania-Pramanik J. Molecular mechanisms in progression of HPVassociated cervical carcinogenesis. J Biomed Sci. 2019;26(1):28. https://doi. org/10.1186/s12929-019-0520-2.

2. Soto D, Song C, McLaughlin-Drubin ME. Epigenetic alterations in human papillomavirus-associated cancers. Viruses. 2017;9(9):248. https://doi.org/1 0.3390/v9090248.

3. Zheng Z-M. Viral oncogenes, noncoding RNAs, and RNA splicing in human tumor viruses. Int J Biol Sci. 2010;6(7):730. https://doi.org/10.7150/ijbs.6.730.

4. Chen J. Signaling pathways in HPV-associated cancers and therapeutic implications. Rev Med Virol. 2015;25:24-53. https://doi.org/10.1002/rmv.1823.

5. Senapati R, Senapati NN, Dwibedi B. Molecular mechanisms of HPV mediated neoplastic progression. Infect Agent Cancer. 2016;11(1):59. https:// doi.org/10.1186/s13027-016-0107-4.

\footnotetext{
* Correspondence: sadhana_gupta@rediffmail.com

Department of Infectious Diseases Biology, National Institute for Research in

Reproductive Health, J.M. Street, Parel, Mumbai 400012, India
}

(c) The Author(s). 2019 Open Access This article is distributed under the terms of the Creative Commons Attribution 4.0 International License (http://creativecommons.org/licenses/by/4.0/), which permits unrestricted use, distribution, and reproduction in any medium, provided you give appropriate credit to the original author(s) and the source, provide a link to the Creative Commons license, and indicate if changes were made. The Creative Commons Public Domain Dedication waiver (http://creativecommons.org/publicdomain/zero/1.0/) applies to the data made available in this article, unless otherwise stated. 